\title{
Islamic Credit Card: Are Demographic Factors a Good Indicator?
}

\author{
Norudin Mansor \\ Faculty of Business Study \& Academy of Language Study \\ Universiti Teknologi MARA (UiTM) \\ Dungun Campus, Dungun 23000, Malaysia
}

Tel: 60-1-3923-1060Ｅ-mail: norudinm@tganu.uitm.edu.my

Azman Che Mat

Faculty of Business Study \& Academy of Language Study

Universiti Teknologi MARA (UiTM)

Dungun Campus, Dungun 23000, Malaysia

Tel: 60-1-3981-8980Ｅ-mail: azman531@tganu.uitm.edu.my

\begin{abstract}
This study investigates on the relationship between demographic factors and the usage of Islamic credit card as well as Conventional credit card demonstrates their interdependencies. The debatable issues as been addressed by many authorities not only in terms of the numbers of credit card flooding the nation's economy, but the amount of transactions that end up with payment default and the numbers of credit card fraud as been recorded which threatened the economy should be seriously focused. Nevertheless the advances and changing habits in purchasing activities significantly contributed the diffusion of credit card as becoming more important and relevant in maintaining the purchasing activities. The study was conducted involving 305 respondents as a sample of study. While 26 items were used for addressing the research questions. Section A of the questionnaire seeks for information concerning the demographic profile of the respondents whilst section $\mathrm{B}$ and $\mathrm{C}$ that used Likert scale aimed to investigate information related to income and usage of credit card. The results of the study offer certain important managerial implications for the policy makers, finance institutions and the authorities bodies that take controls the credit card activities.
\end{abstract}

Keywords: Islamic Banking, Islamic Credit Card, Income

\section{Introduction}

Credit cards or charge cards, like Visa, MasterCard, Diners Club, American Express and others including Affinity Cards, are basically lines of credit that once established, depending on the terms, allow an individual to spend certain allowable sum of money and pay back the amount either in monthly or full amount (Norudin \& Zull Nikli, 2005). An intensified interest in the marketing of credit cards not only throughout the nation but most of the countries in the world. The organizations involved constantly seek to produce distinct market segments and differentiated services (Ali Kara et. al, 1994) so as to remain competitive in the business.

Due to aggressiveness of the competition some institutions, strengthen their credit card activities through coordination with retailers so as to ensure that their cards are most acceptable, preferable and more convenient in handling purchasing transaction (Howarth, 1990). Using the affinity cards as an example, not only provides conveniences for settling payment at affiliated retail outlets, but constitutes a strong incentive for the purchasing transactions to use card at certain price discounts and other specified privileges.

Since the introduction of the first credit card in 1914 by Western Union in the USA, as for the year 1995 there were 36,000 banks issuing 450 million credit cards throughout the world (Kaynak et al, 1995). Certain nations like United States, United Kingdom, and Hong Kong found the industries were saturating while some others like Malaysia, Turkey, Greece are actively promoting individuals to own and spend through credit cards. For the year 2002 there are 3.6 million credit cardholders in Malaysia that spent RM21billion on the transaction (Kazi Mahmood, 2002) and the rapid 
increasing in usage trend is reflected with approximately 5.3 million credit card holders as at October 2004. Comparing to other countries in the region, the penetration rate in Malaysia is still relatively low with Singapore, Korea, Japan, Hong Kong, Taiwan, and Malaysia at 90\%, 90\%, 85\%, 80\&, 70\% and 23\% respectively (Bank Negara Malaysia, 2004).

The Islamic banking in Malaysia started its predation in early eighties with the establishment of the first Islamic Bank that is Bank Islam Malaysia Berhad (BIMB) in March 1983. After almost 20 years in the industry then the first Islamic Credit card was introduced in Malaysia under the name of al-Taslif by Am Bank of Malaysia (Ahmed Fouad Darwish, 2003) followed by Bank Islam Credit card that was launched in 2002 (Kazi Mahmood, 2002). Several other related regulations had to be amended so that Islamic banks can abide with the rules imposed on commercial banks and not going against the Islamic (Syaric ${ }^{c}$ ah) principles, Thus it can attract those Muslim that are not using the conventional banking system and financial services due to the forbidden of interest element in conventional banking for mobilizing and disbursing funds which help to widen and deepen the country's financial system. Bank Islam Credit Card (BIC) as an example work on the Islamic (Syari $\left.{ }^{c} a h\right)$ which comprise of two agreements. In the first agreement, the bank sells a piece of land to the customer at an agreed price. While in the second agreement, the Bank will repurchase the land from the customer at a lower price. The difference in the price is therefore the Bank's predetermined maximum profit, unlike the conventional credit card whereby the interest charge is determine as a profit.

Among the newly developed nations, most of the credit cardholders are urban dwellers, with a higher level of education, and working as professionals (Kaynak et al, 1995). Empirical evidence in previous study by Labich (1994) and Schaninger's (1981) suggest that social stratification based on income has significant influence the usage of credit card. Further evidence on the profile in terms of education, income, residence, family and age (Meidan \& Davo, 1994) support the same findings. Even though all these demographic indicators have continuously been supported by previous research but still it ability to generalize throughout many nations is not significant enough.

\section{Relationship between Demographic (Income) and the Usage of Credit Card}

Previously the work of Chan (1997) highlighted that there was positive association between usage rate and income. This is due to the fact that most of the card issuers normally grant a higher credit limit among the higher income group. At the same time the wealthier cardholders many times prefer to use credit card in their purchasing transactions.

Indeed, income can be explained as disposable earning that someone's obtained after taxes which is complemented by gifts, pension, cash saving or other assets the family may have to meet its expenditure (McCarthy et al, 1997) as well as all kind of worked-related pay or rewards that go to the employees such as wages, salaries, incentives, commissions and bonuses, as well as indirect payments in the form of financial fringe benefits like employer paid insurance and vacations (Dessler, 2001). In fact, income also acts as a factor in determining of how much the purchasing power of consumers will be spent on goods or services (Allvine, 1987). Likewise, occupation and income are generally accepted as one of the most popular indicator that explained and significantly correlates with the usage of credit card (Frank et al, 1965)

Historical evidence demonstrated that the rising income and the increased in the purchasing power of the household are among the most significant factors during the 1982s and 1990s that resulted in increasing demand for credit card facilities (Kara et al, 1994). Therefore it is interesting to develop a profile of spending pattern resulted from the income generated. Thus, Ching (1976) highlighted that income that is derived by the family should aimed at meeting family expenses. It is therefore becoming an important decision that need to be established whether to spend all the money or to invest in certain schemes with the expectation to earning for further use. However study by Cairncoss (1696) and Ahmad Khalid (1980) demonstrated that every income derived from the income earlier generated, may not end up with full saving but rather likely to be spent as to match the standard of living. Thus the use of credit card served as an alternative to facilitate earlier spending.

The relationship between spending, desirability with income earned experiencing dramatic charges in the past few years (Sutherland \& Canwell, 1994). Those with more disposable income discovered to indulge with leisure and social activities. To some extent, it led users to incur debt credit card which allow them to spend beyond their means. It is becoming a trend that consumers today live beyond their financial capacity, and not realizing that their expenditures consistently exceed their income (Mapother, 1999). With the accessibility of using credit card people grew up with debt and using credit freely (Warwick and Mansfield, 2000). The desire to spend more are further enhanced as Buttle (1996) describe the important of credit card in term of its ability to offer substantial income steam due to the availability of card-protection insurance policies. Some of the benefits could be the coverage in case of losing credit card, accident while on trips, the cardholder becoming unemployed or ill, where the difficulties will be place on the insurance. With such a provision, plus the surge of spending on credit cards and the worldwide acceptance of the major card association brands, the credit card has been not only a profitable element but a highly convenience tool for purchasing transactions. Evidence suggested by Feinberg (1986) demonstrated that the usage of credit card are conditioned with spending behaviors that support one does not have to worry about carrying cash. Other added factors are the additional safety, the extended credit, less spending effort, convenience time, and less problems in dealing with currency exchange. 
Higher income consumers are the main target for the credit card issuers. The general assumption suggested that when consumers seek for resolution to credit card problems, more likely it may not be a troublesome to the higher income group, but the evidence demonstrated otherwise (Hogart et al, 2004). However studies by Mandell (1972) followed by Awh and Walters (1974) revealed that family income, education and socio-economic standing were the main determinants for credit card usage. This could be due to the focus of their marketing strategy were among the higher income group. The study further supported the investigation on credit and charge card in Greece where most of the users are those living in urban areas where the average income is much higher than those living in rural areas.

\section{Investigation Issues and Purpose of the Study}

The attractiveness of credit card facilities holds under the beauty of its permissibility for purchasing good and services within the credit limit even when funds are low. In fact the product also act as an alternative to short term-borrowing at the convenience of the user without going though the formal application process. Islam prohibits interest (Islamic term is riba) (Al-Baqarah: 278-281; Ali 'Imran: 130; Al-Nisa': 161; Al-Rum: 39) in the strongest terms and aims at establishing an economy free not only from all form of Credit Card provides a credit line that has the same functions as the other major credit card issuers. But, the perception of people towards some of the Islamic term in this Banking Institution in general and Islamic Credit Card in particular is a hindrance for promoting and attracting customers throughout the nation. With the diffusion of knowledge about Islamic Credit Card more institutions are now offering the facility as an alternative to conventional credit card.

Previous research suggests that the functions of demographic variables are very much related to the reason for owning and using credit card in a developed nation. This investigation partly focused on income as one of the primary determinants towards the usage of Islamic and Conventional Credit Card. Other major research questions addressed in this study are:

- What are the factors affect the credit card choice decision?

- Is there any significant relationship between income attribute towards the usage of credit card?

- Is there a significant different between income group as to the usage of credit card?

- Is there a significant different between level of education as to the usage of credit cards?

- Is there a significant different between gender as to the usage of credit cards?

\section{Research Framework}

The framework demonstrates that the main variable of investigations is the usage of credit card while demographic elements are the determinants for the credit card usage.

Schematic diagrams for the theoretical framework

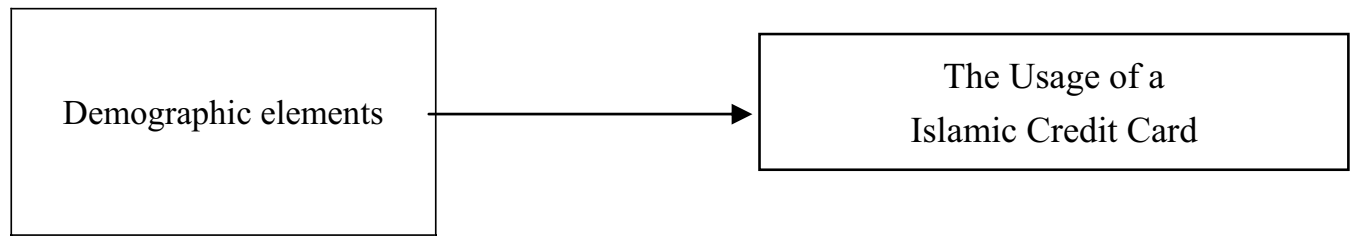

\section{Significance of the Study}

This study aims to provide the Islamic Baking Institutions with critical analysis towards improving their operations, services, and performance, which eventually address the customer's satisfaction issues. A better perception and awareness could be developed among the societies regardless of their religious beliefs as to the special features of Islamic Credit Card which is obviously in parallel with the (Islamic) Syaric ah principles that aimed to provide better alternatives to the user. The result of the study also offers important managerial implications for the policy makers such as Central Banks in controlling the flooding of the unhealthy customers practices.

\section{Methodology}

The sample frame for the study was selected from the respective registrar office of each college. This investigation adopted the personally administered questionnaire to collect the data from the respondents that covers professors, associated professors, lecturers, assistant lecturers and also tutors from seven Public Higher Education Learning in the State of Kelantan and Terengganu. Following the suggestion by Krejcie and Morgan (1970), with the population size of 1880, the recommended appropriate sample size should be 291 respondents (305 used for the study). The study, adopted quota sampling as the target population is known and they were chosen according to their willingness to give the commitment to answer the questionnaire. 
The operationalization of the instruments has been developed with some changes been introduced after conducting a pilot test that on 30 respondents. The earlier investigation was discovered to be lacking of consistencies. Finally, 26 items were used for addressing the research questions. Section A of the questionnaire seeks for information concerning the demographic profile of the respondents whilst section $\mathrm{B}$ and $\mathrm{C}$ that used Likert scale aimed to investigate information related to income and usage of credit card. Data for the study were collected by personally administering the questionnaire.

\section{Findings, Discussion and Conclusion}

All variables in this study are reliable and acceptable with the Cronbach alpha value fall of 0.7 above (Hair et al., 2003). The finding confirmed that income is a good predictor of the credit card user. The present study has compared users of Islamic Credit Card and Conventional Card, or those using both using the survey method. As far as dimensions concerning demographic, income as a dimension was found to be the single most important variable. However when referring to opinion of how income is to be spent by using credit card, the findings demonstrated that the influence is very weak. Theoretically, consumers tend to increase their spending pattern when their income increases. The factor of income level that is assumed to be highly correlated with social class is positively significant to the usage of credit cards. As suggested by previous findings there are strong evidence that social class affect the use of income (Sivadas, 1997; Levy, 1992). For some consumers an increase in income stimulates them to continuously demand quality product, better standard of living, better services, and increased spending in satisfying secondary needs. Given the choice of its usefulness, availability, and values attached to the card, the strength of Conventional Credit Card still supersede Islamic Credit Card.

In addressing the issue of does credit card make living more comfortable or vulnerable should not be overlooked. Those owners who are relatively new and just meet the minimum requirement to use credit card seem to be lacking of the understanding about the "Trade-off" that most credit card offer. As a result of aggressive marketing efforts targeted to these users, the facilities offered put them at the disadvantage corner rather then making them more convenience. The fees and interest charge, the attractiveness of incentives offered, and over- extended credit limit (Kaynak et al, 1995; Sullivan, 1992) if poorly managed will make life more miserable. This evidence should placed Islamic Credit Card in a better position then the Conventional Card. However, still people put their preferences towards using more Conventional rather then Islamic Credit Card.

The rate of credit card usage is very much related to the issues of its ability to encourage the cardholders to undertake the purchasing transactions by means of credit card. Whilst factors like convenience in purchasing and payment transactions resulted in saving time instead of queuing, traveling time to point of purchasing or point of payment are a very much concerned to the middle income group as these unnecessary time could be utilized for other meaningful activities. The popularity of today's advertising campaign that encourage consumers to spend such as "buy now pay later" make consumers attracted to spend more especially the convenience credit attached to either conventional or Islamic Credit Card. The major promotional tools use by Institutions promoting Islamic Credit Card is through advertising while some others move on a advertising their products via Internet, newspaper, magazines, billboards and aggressively set-up promotion counters at shopping malls or exhibition centers and various promotional gifts such as cameras, watches, traveling bags, and other attractive items.

Using advertising as promotional tools becomes a major concern for most of the company to promote their product. Advertising has an ability to strike a responsive chord with consumers when differentiation across other elements of the marketing mix is difficult to achieve (George and Michael 1998). The ability to create differentiation may provide distinct advantage about the specialty of product like Islamic Credit Card Thus attracting the consumers' attention to use it. The right promotion strategy will further instilled the confident that could enhance the use of Islamic Credit Card. Indeed, lack of promotional activity is often an indicator of lack of anything to promote (Hart, 1993).

According to Phoon (1993), the fact that Islamic banking practice is still new and at infant stage, it is usual for things less understood to be viewed with mixture of curiosity and skepticism. It was a daunting task putting up together the scattered Islamic business transaction concepts turning it into reality from banking perspective as the commercial banking system has served Malaysian needs for almost a past century ago. Getting more people to use Islamic Credit Cards could be s strong challenge as more of the issuers are offering the cardholders with more attractive benefits and incentives (Kaynak et al, 1995) Islamic banking should seriously review its strategic planning in order to achieve its missions and objectives through focusing their target market. In order to enhance the organizations' performance, a company such as Bank Islam Malaysia Bhd. (BIMB) should study the external opportunities and threats as well as internal strengths and weaknesses rather than assuming that the industry is doing fine. Institutions offering Islamic Credit Card should increase their promotion strategy so as to enhance the customer' awareness especially when new products or services are entering the market. BIMB should aggressively use this tool in order to reach the segmented market if they wish to get more customers for Bank Islam Card holders (Norudin \& Zull Nikli, 2005).

There are no statistical differences between males and females in the use of credit card. However when considered the 
variables pertaining to levels of education and income, there is a sign of certain degree of differences appeared to exist when observing the three levels of education and the four levels of income. It seems that among those with lower and middle income are prone to use credit cards as it is able to provide safety and convenience features.

\section{Future Research Directions}

Further research could be developed by demonstrating the differences in terms of usage rate among the owners of credit card. Through the understanding of these differences it may provide an indication of does the culture of spending using credit card is accepted on nationwide basis? Does the issue of credit card centers more on a tool for getting credit rather then facilitating purchasing transactions?

Previous literatures demonstrated that no investigation reported concerning on the guidelines to the managers of credit card institutions on how the new credit card owners make decisions among the available facilities offered. The understandings of this development are expected to provide the strength and limitations of their operations which may eventually create more and better alternative to the credit card users.

As this study only focus on the usage of Islamic Credit Card as well as the Conventional Card in both state of Terengganu and Kelantan, additional studies are needed to examine the usage behavior of the general populations especially those living in rural, urban and semi-urban areas where the application of the facilities is very much related to the diffusion process of its usefulness.

\section{References}

Abdullah Yusuf Ali. (1998). The Meaning of Holy Qur'an. U.S.A: Amana Publications.

Ahmad Khalid. (1990). Student in Islamic Economics. Kuala Lumpur: International Centre for Research in Islamic Economies.

Ahmed Fouad Darwish. (2003). Can A Credit Card Ever Be Halal. [Online] Available: http://www.bankerme.com/bme/2003/mar/Islamic_banking.asp (Mar 22, 2003)

Ali Kara, Kaynak, E. \& Kucukemiroglu. (1994). Credit Card Development Strategies for theYouth Market: The Use of Conjoint Analysis. International Journal of Bank Marketing, 12(6), 30-36.

Allvine, F.C. (1987). Marketing-Principle and Practice. U.S.A: Harcourt Brace Jovanovich Publisher.

Awh, R.Y. and Walters, D. (1974). A Discriminant Analysis of Economy Demographic or Attitudinal Characteristics of Bank Charge Credit Card Holders: A Case Study. Journal of Finance, 29(3).

Bank Negara Malaysia’s Report. (2004). Monetary and Financial Development Highlights of the Press Release. Kuala Lumpur: Bank Negara.

Buttle, F. (1996). Relationship Marketing: Theory and Practice. London: Paul Chapman Publishing Ltd.

Chan, Y.K. (1997). Demographic and Attitudinal Differences between Active and Inactive Cardholders: the Case of Hong Kong. International Journal of Bank Marketing, 15(4), 117-125.

Ching, L.S. (1976). Land Development Schemes in Peninsular Malaysia. Kuala Lumpur: Rubber Research Institute of Malaysia.

Dessler, G. (2001). Management. $3^{\text {rd }}$ Ed. U.S.A: Pearson Education Inc., New Jersey.

Feinberg, R.A. (1986). Credit Card as Spending Facilitating Stimuli: A Conditioning Interpretation. Journal of Consumer Research, 13(3), 348-355.

Frank, R.E \& Massy, W.F., and Morrison, D.G. (1965). Bias in Discriminate Analysis. Journal of Marketing Research, 2(3), 250-258.

George, E.B \& Michael, A.B. (1998). Advertising \& Promotion- An Integrated Marketing Communication Perspective. $4^{\text {th }}$ Edition. U.S.A: McGraw-Hill Inc.

Hair, J.F., Babin, B., Money, A.H. \& Samouel, P. (2003). Essentials of Business Research Methods. U.S.A: John Wiley \& Sons, Inc.

Hart, N.A. (1993). Industrial Marketing Communications-Advertising: PR and Promotion. London: Kogan Page Ltd.

Howarth, C. (1990). Going Gets Tough in Hong Kong Credit Card Boom. Amcham, 22(11), 47-9.

Kara, A, Kaynak, E. and Kucukemiroglu, O. (1994). Credit Card Development Strategies for the Youth Market: The Use of Conjoint Analysis. International Journal of Bank Marketing, 12(6), 30-36.

Kaynak, E., Kucukemiroglu, O. and Ozmen, A. (1995). Correlates of Credit Card Acceptance and Usage in an Advance Developing Middle Eastern Country. Journal of Service Marketing, 9(4), 52-63.

Kazi Mahmood. (2002). Malaysian Banks Launches First Islamic Credit Card In Asia, [Online] Available: 
http://www.islam-online.net/English/News/2002-07/25/artcles06.shtml. (December 28, 2004)

Krejcie, R. \& Morgan, D. (1970). Determining Sample Size for Research Activities. Sekaran, U. (ed). Research Methods for Business- A Skill Building Approach. $4^{\text {th }}$ Edition, John Wiley \& Sons, Inc., 293.

Labich, K. (1994). Class in America. Fortune Magazine. [Online] Available: http://money.cnn.com/magazines/fortune/fortune_archive/1994/02/07/78932/index.htm. (September 16, 2009).

Mandell, L. (1972). Credit Card Use in the United States. MI: University of Michigan Press, Ann Arbor.

Mapother, B. (1999). The Real Cause of Bankruptcy. Credit Union Magazine, 65(6), 78.

McCarthy, E.J., Perreault, W.D., \& Quester, P.G. (1997). Basic Marketing-A Managerial Approach. Australia: McGraw-Hill Book Co. Pte. Ltd.

Meidan, A. \& Davo, D. (1994). Credit and Charge Card Selection Criteria in Greece. International Journal of Bank Marketing, 12(2), 36-44.

Norudin Mansor \& Zull Nikli. (2005). Islamic Credit Card Usage in Working Middle-Class. Paper presented at The Malaysian Finance Association $7^{\text {th }}$ Annual Conference. UiTM Terengganu and MFA, Kuala Terengganu.

Phoon, Z. (1993). Islamic Banking a Rapid Progress. Investor Digest (ed.) Mid April 1993. Kuala Lumpur Stock Exchange, 11-19.

Schaninger, C.M. (1981). Social Class versus Income Revisited: An Empirical Investigation. Journal of Marketing Research, 18(2), 192-209.

Sullivan, M.P. (1992). Bank Marketing Strategy: Reshuffling the Cards. Bankers Monthly, November, 27.

Warwick, J. \& Mansfield, P. (2000). Credit Card Consumers: College Students' Knowledge and Attitude. Journal of Consumer Marketing, 17(7), 617-626. 
Table 1. Respondents' Profile

\begin{tabular}{|c|c|c|}
\hline Profile $(n=305)$ & Frequency & Percent (\%) \\
\hline \multicolumn{3}{|l|}{ State } \\
\hline Kelantan & 180 & 59.0 \\
\hline Terengganu & 125 & 41.0 \\
\hline \multicolumn{3}{|l|}{ Gender } \\
\hline Male & 181 & 59.3 \\
\hline Female & 124 & 40.7 \\
\hline \multicolumn{3}{|l|}{ Marital status } \\
\hline Single & 47 & 15.4 \\
\hline Married & 254 & 83.3 \\
\hline Divorced & 4 & 1.3 \\
\hline \multicolumn{3}{|l|}{ Educational Level } \\
\hline Degree & 12 & 3.9 \\
\hline Master & 228 & 74.8 \\
\hline Ph.D & 65 & 21.3 \\
\hline \multicolumn{3}{|l|}{ Income Level } \\
\hline$<$ RM 3000 & 120 & 39.3 \\
\hline RM $3001-5000$ & 102 & 33.4 \\
\hline RM 5001 above & 83 & 27.2 \\
\hline \multicolumn{3}{|l|}{ Owned Credit Card } \\
\hline Yes, Conventional & 178 & 58.4 \\
\hline Yes, Islamic & 79 & 25.9 \\
\hline Yes, Both & 48 & 15.7 \\
\hline
\end{tabular}

Table 1 indicates that 59.3 percent of the respondents were male, 40.7 percent derived from female and 83.3 percent were married. In term of educational level 74.8 percent were having Master Degree, while $21.3 \%$ with a Doctoral Degree (PhD). For the income level 39.3\% were receiving below than RM 3000, 33.4\% ranging from RM 3001 to RM $5000,27.2 \%$ were above RM 5000 income category. Among those who owned or using credit card, more than half of the respondent with 58.4\% owned conventional credit card, $25.9 \%$ owned an Islamic credit card, and $15.7 \%$ owned both cards. 
Table 2. Cross tabulation table between Gender, Income categories and Education level with the usage of credit card

\begin{tabular}{|c|c|c|c|c|}
\hline & Low Usage & Medium Usage & High Usage & Total $(100 \%)$ \\
\hline Gender & & & & \\
\hline Male & $2(1.1 \%)$ & $113(62.43 \%)$ & $66(36.46 \%)$ & 181 \\
\hline Female & $0(0 \%)$ & $76 \quad(61.29 \%)$ & $48(38.71 \%)$ & 124 \\
\hline Income Categories & & & & \\
\hline$<3000$ & $0(0 \%)$ & $78(65 \%)$ & $42(35 \%)$ & 120 \\
\hline RM 3001 - RM 5000 & $1(0.98 \%)$ & $63(61.76 \%)$ & $38(37.25 \%)$ & 102 \\
\hline RM 5001 - RM 7000 above & $1 \quad(1.2 \%)$ & $48(57.83 \%)$ & $34(40.96 \%)$ & 83 \\
\hline Education Level & & & & \\
\hline Bachelor & $0(0 \%)$ & $8(66.67 \%)$ & $4(33.33 \%)$ & 12 \\
\hline Master & $1(0.44 \%)$ & $139(60.96 \%)$ & $88(38.60 \%)$ & 228 \\
\hline Ph.D & $1(1.54 \%)$ & $42(64.62 \%)$ & $22(33.85 \%)$ & 65 \\
\hline
\end{tabular}

The cross-tabulation analysis from table 2 indicated that the usage of credit card (Conventional Card, Islamic Card and Both Card) based on gender, income categories and educational level displayed almost the same pattern. Most of the users are using the facilities considerably and only a small percentage hardly use the card for their purchasing transactions.

Table 3. Correlations between Income elements with the usage of credit card

$\begin{array}{llcc} & \text { M_E } & \text { MDEP } \\ \text { M_E } & \text { Pearson Correlation } & 1.000 & .222 \\ \text { Sig. (1-tailed) } & . & .000 \\ \text { N } & 305 & 305\end{array}$

** Correlation is significant at the 0.01 level (1-tailed)/

As indicated in Table 3, Pearson correlation coefficient computed between income as the predictor to the usage of credit card as the dependent variable indicated that there is a positive relationship but the strength of the relationship is very weak at $\mathrm{p}=0.222$. 
Table 4a. Usage of Credit Card based on Educational level

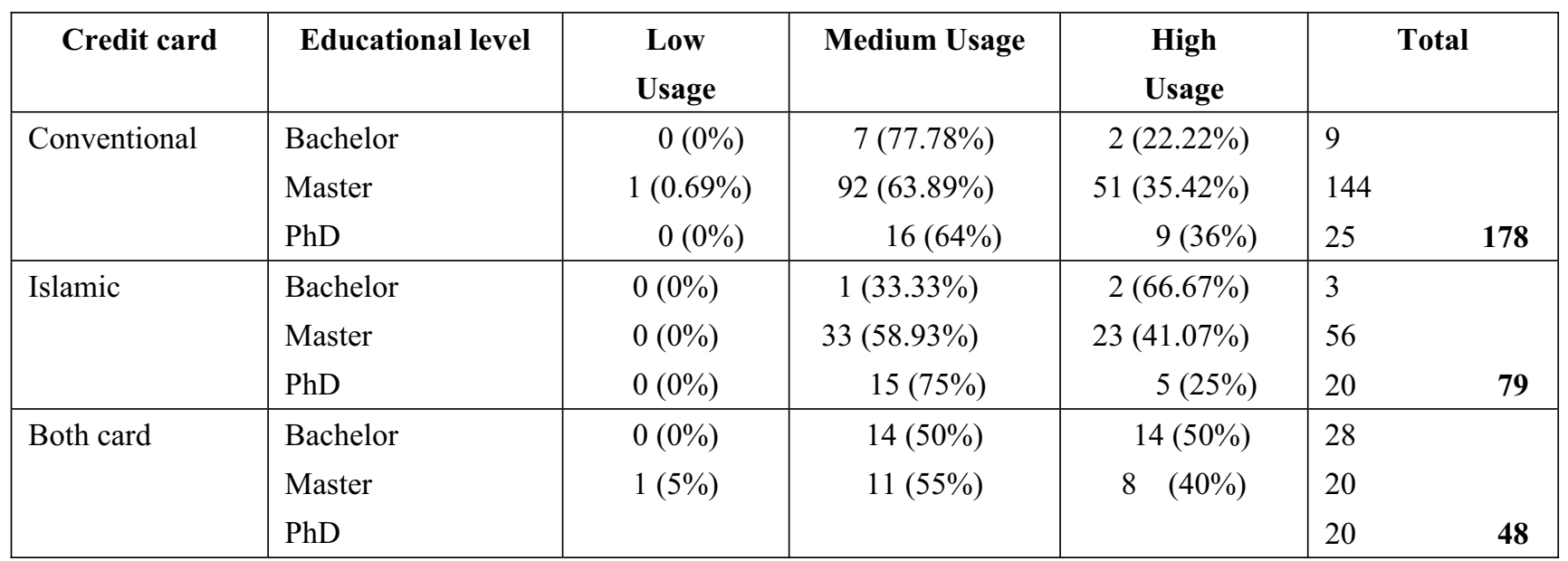

The result demonstrated that among those with degree qualification, most of them actively use conventional credit card (75\%: 9/12), and 25\% (3/12) were using Islamic Credit Card. Those with Master Degree qualification indicated the similar trend where $63.16 \%$ (144/228) actively used conventional card, $24.56 \%(56 / 228)$ were using Islamic Credit Card, and 8.77\% (20/228) were using both. Another qualification measurement is based on those with Doctorate Degree. Again the finding is in favor of conventional card, followed by Islamic Credit Card, and both card with 38.46\% (25/65), and $30.77 \%(20 / 65)$ respectively.

Table 4b. Usage of Credit Card based on Income level

\begin{tabular}{|c|c|c|c|c|c|c|}
\hline Credit Card & Income & Low Usage & Medium Usage & High Usage & \multicolumn{2}{|c|}{ Total } \\
\hline \multirow[t]{3}{*}{ Conventional } & $<$ RM 3000 & $0(0 \%)$ & $60(67.42 \%)$ & $29(32.58 \%)$ & 89 & \\
\hline & RM 3000-5000 & $1(2 \%)$ & $33(66 \%)$ & $16(32 \%)$ & 50 & \\
\hline & RM 5000 above & $0(0 \%)$ & $22(43.59 \%)$ & $17(43.59 \%)$ & 39 & 178 \\
\hline \multirow[t]{3}{*}{ Islamic } & $<$ RM 3000 & $0(0 \%)$ & $15(60 \%)$ & $10(40 \%)$ & 25 & \\
\hline & RM 3000-5000 & $0(0 \%)$ & $19(61.29 \%)$ & $12(38.71 \%)$ & 31 & \\
\hline & RM 5000 above & $0(0 \%)$ & $15(65.22 \%)$ & $8(34.78 \%)$ & 23 & 79 \\
\hline \multirow[t]{3}{*}{ Both card } & $<$ RM 3000 & $0(0 \%)$ & $3(50 \%)$ & $3(50 \%)$ & 6 & \\
\hline & RM 3000-5000 & $0(0 \%)$ & $11(52.38 \%)$ & $10(47.62 \%)$ & 21 & \\
\hline & RM 5000 above & $1(4.7 \%)$ & $11(52.38 \%)$ & $9(42.86 \%)$ & 21 & 48 \\
\hline
\end{tabular}

The popularity of credit usage is reflected in term of the income status category among the respondents. Those earning less than RM3000.00 constitute the majority of the usage followed by those within income category between RM3000.00-RM5000.00, and those earning more than RM5000.00. Of those earning less than RM3000.00, 74.17\% were using conventional card, 20.83\% were Islamic Credit Card and only 5\% were using both card. For those within the income category of between RM3000.00 to RM5000.00, 49.03\% were using conventional card, 30.39\% using Islamic Credit Card, and $20.58 \%$ were using both. The similar trend could be observed among those income group of more than RM5000.00 where conventional card is most preferable use (46.98\%), followed by Islamic Credit Card (27.72\%), and for both card $(25.30 \%)$. 
Table 4c. Usage of Credit Card based on Marital Status

\begin{tabular}{|l|l|r|r|r|ll|}
\hline \multicolumn{1}{|c|}{ Credit card } & \multicolumn{1}{|c|}{$\begin{array}{c}\text { Marital } \\
\text { status }\end{array}$} & Low Usage & $\begin{array}{c}\text { Medium } \\
\text { Usage }\end{array}$ & $\begin{array}{c}\text { High } \\
\text { Usage }\end{array}$ & \multicolumn{2}{|c|}{ Total } \\
\hline Conventional & Single & $0(0 \%)$ & $22(75.86 \%)$ & $7(24.14 \%)$ & 29 & \\
& Married & $1(0.68 \%)$ & $93(63.70 \%)$ & $52(35.62 \%)$ & 146 & \\
& Divorced & $0(0 \%)$ & $0(0 \%)$ & $3(100 \%)$ & 3 & $\mathbf{1 7 8}$ \\
\hline Islamic & Single & $0(0 \%)$ & $5(71.43 \%)$ & $2(28.57 \%)$ & 7 & \\
& Married & $0(0 \%)$ & $43(60.56 \%)$ & $52(35.62 \%)$ & 71 & \\
& Divorced & $0(0 \%)$ & $1(100 \%)$ & $3(100 \%)$ & 1 & $\mathbf{7 9}$ \\
\hline Both card & Single & $1(9.09 \%)$ & $6(54.55 \%)$ & $4(36.36 \%)$ & 11 & \\
& Married & $0(0 \%)$ & $19(51.35 \%)$ & $18(48.65 \%)$ & 37 & $\mathbf{4 8}$ \\
\hline
\end{tabular}

The figure mentioned earlier indicated that conventional cards are still more preferable than Islamic credit card. Out of those married 57.48\% (146/254) used conventional card, 27.95\% (71/254) used Islamic Credit Card, and 14.57\% (37/254) are using both card (see table 4a). Of those with single status $61.70 \%(29 / 47)$ used conventional card, $14.89 \%$ (7/47) used Islamic Credit Card, and $23.40 \%$ (11/47) are using both card (see table 4c).

Table 4d. Usage of Credit Card based on Gender

\begin{tabular}{|l|l|c|c|c|cr|}
\hline \multicolumn{1}{|c|}{ Credit card } & Gender & Low Usage & Medium Usage & $\begin{array}{c}\text { High } \\
\text { Usage }\end{array}$ & \multicolumn{2}{|c|}{ Total } \\
\hline Conventional & Male & $1(0.95 \%)$ & $69(65.71 \%)$ & $35(33.33 \%)$ & 105 & \\
& Female & $0(0 \%)$ & $46(63.01 \%)$ & $27(36.99 \%)$ & 73 & $\mathbf{1 7 8}$ \\
\hline Islamic & Male & $0(0 \%)$ & $31(63.27 \%)$ & $18(36.73 \%)$ & 49 & \\
& Female & $0(0 \%)$ & $18(60 \%)$ & $12(40 \%)$ & 30 & $\mathbf{7 9}$ \\
\hline Both card & Male & $1(3.7 \%)$ & $13(48.15 \%)$ & $13(48.15 \%)$ & 27 & \\
& Female & $0(0 \%)$ & $12(57.14 \%)$ & $9(42.86 \%)$ & 21 & $\mathbf{4 8}$ \\
\hline
\end{tabular}

The analysis on gender further indicated that both male and female respondent were using more conventional card, followed by Islamic Card, and some of the used the combination of both. For the male, $58.01 \%, 27.01 \%$, and $14.9 \%$ and for the female, $58.87 \% ; 24.20 \%$ and $16.93 \%$ respectively used Conventional, Islamic and both credit card.

Table 5. Chi-Square Tests of gender, income categories, and educational level with usage of credit card

\begin{tabular}{lccc}
\hline & Value & df & Asymp. Sig (2-sided) \\
\hline Pearson Chi-Square & & & .850 \\
Gender & 13.608 & 20 & .541 \\
Income Categories & 38.435 & 40 & .746 \\
Educational Level & 33.753 & 40 & \\
\hline
\end{tabular}

The study further explore whether is there any differences in terms of several demographic variables as to the use of credit card. Using the Pearson Chi-Square score indicated that there is no significant different between all the three demographic variables as to the usage of credit card with the Significant value of $r=0.850,0.541$, and 0.746 . 